\title{
Basicities of the Oxygen Atoms in Symmetrical and Unsymmetrical Acetals. Part I. The Determination of Base Strengths by Infrared Spectroscopy
}

\author{
A L P O K A NKA A N P E R Ä \\ Department of Chemistry, University of Turku, Turku, Finland
}

\begin{abstract}
The basicities of sixteen acetals of formaldehyde (dialkoxymethanes) $\mathrm{R}_{n} \mathrm{OCH}_{2} \mathrm{OR}_{m}$ with different alkyl groups $\left(\mathrm{CH}_{3}, \mathrm{CH}_{3} \mathrm{CH}_{2}\right.$, $\left(\mathrm{CH}_{3}\right)_{2} \mathrm{CH}, \quad\left(\mathrm{CH}_{3}\right)_{3} \mathrm{C}, \mathrm{ClCH}_{2} \mathrm{CH}_{2}, \mathrm{FCH}_{2} \mathrm{CH}_{2}, \mathrm{Cl}_{3} \mathrm{CCH}_{2}, \mathrm{~F}_{3} \mathrm{CCH}_{2}$, and $\mathrm{C}_{6} \mathrm{H}_{5}$ ) were determined by a spectral shift method. The validity of this method was checked by measuring the $\mathrm{O}-\mathrm{D}$ band shifts for methanol- $d_{1}$ in ethers whose basicities are known. The $\mathrm{p} K_{\mathrm{a}}$ values of the protonated forms of the different oxygen atoms in acetals were calculated from the measured basicities.
\end{abstract}

Tn a previous study, Salomaa ${ }^{1}$ determined the contributions of different 1 fission reactions in the hydrolysis of unsymmetrical and symmetrical acetals. These partial rate coefficients are products of two factors; the equilibrium constant of the protonation and the rate coefficient of unimolecular decomposition of the protonated substrate. To determine the effects of these two factors on the partial rates, the basicities of both oxygen atoms of the acetal must be known.

Because acetals are readily hydrolyzed, their $\mathrm{p} K_{\mathrm{a}}$ values cannot be measured in strong aqueous acids. It has previously been found, however, that a number of organic bases influence the stretching frequency of the bond of the acidic hydrogen in deuteromethanol. ${ }^{2}$ Because the magnitude of this effect has been shown to be proportional to the $\mathrm{p} K_{\mathrm{a}}$ value of the solvent, the hydrogen bond shift method was applied to determine the basicities of acetals.

\section{EXPERIMENTAL}

Materials. Most of the dialkoxymethanes studied in this work were those previously prepared in this laboratory by Salomaa. ${ }^{1}$ The fractions which were used for the $p K_{\mathrm{a}}$ measurements were purified by distillation from metallic natrium. The purities of these fractions were checked by gas chromatography. Di- $\beta, \beta, \beta$-trichloroethoxymethane and

Acta Chem. Scand. 23 (1969) No. 5 
isopropoxy- $\beta, \beta, \beta$-trichloroethoxymethane were those prepared by Salomaa and Linnantie. ${ }^{3}$ The syntheses of di- $\beta, \beta, \beta$-trifluoroethoxymethane and diphenoxymethane were carried out in a recent work. ${ }^{4}$

Most of the ethers used as standard liquids in the $\mathrm{p} K_{\mathrm{a}}$ measurements were commercial products which were purified by distillation from metallic natrium. sec-Butyl phenyl ether and $o$-methoxytoluene were prepared by standard methods. ${ }^{5}$ sec-Butyl phenyl ether: b.p. $84-86^{\circ} \mathrm{C} / 18$ torr and $n_{\mathrm{D}}{ }^{20} 1.4941$. $o$-Methoxytoluene: b.p. $172-173^{\circ} \mathrm{C} / 760$ torr and $n_{\mathrm{D}}{ }^{20} 1.5172$. The purities of the ethers were checked by gas chromatography.

$I R$ measurements. The used apparatus was a Perkin Elmer grating infrared spectrometer connected to a Honeywell continuous balance potentiometer to broaden the spectrum. A sodium chloride cell was used. The thickness of the liquid layer was $0.1 \mathrm{~mm}$. The temperature during the measurements was about $25^{\circ} \mathrm{C}$. The possible small variations in temperature did not alter the band shifts within the limits of experimental error as shown by experiments conducted at temperatures between 10 and $50^{\circ} \mathrm{C}$.

About $10 \mu \mathrm{l}$ of methanol- $d_{1}$ was added to $0.5 \mathrm{ml}$ of acetal to give an approximately $0.5 \mathrm{M}$ solution. The reference cell was filled with the solvent. Each measurement was repeated 5-10 times and the relative standard errors (less than $0.03 \%$ ) were calculated. The bands of polystyrene $\left(2850.7,1944.4\right.$ and $\left.1601.4 \mathrm{~cm}^{-1}\right)$ were used as standards from which the frequencies of the $\mathrm{O}-\mathrm{D}$ bands were measured.

\section{RESULTS AND DISCUSSION}

Spectral results. The $\mathrm{p} K_{\mathrm{a}}$ values of only a few acetals have previously been measured. ${ }^{6,7}$ Therefore ethers which are alkyl-substituted oxygen bases like acetals, were chosen as standard substances to evaluate the $\mathrm{p} K_{\mathrm{a}}$ values from the $\mathrm{O}-\mathrm{D}$ band shifts. The nine ethers listed in Table 1 , whose $\mathrm{p} K_{\mathrm{a}}$

Table 1. $\mathrm{O}-\mathrm{D}$ band shifts of methanol- $d_{1}$ in different ethers, the $\mathrm{p} K_{\mathrm{a}}$ values of which have been measured previously by other methods. $25^{\circ} \mathrm{C}$.

\begin{tabular}{lccc}
\hline Compound & $-\mathrm{p} K_{\mathrm{a}}{ }^{2}$ & $\begin{array}{c}\text { Position of } \\
\mathrm{O}-\mathrm{D} \text { band }\left(\mathrm{cm}^{-1}\right)^{a}\end{array}$ & $\begin{array}{c}\mathrm{O}-\mathrm{D} \text { band } \\
\text { shift }\left(\mathrm{cm}^{-1}\right)\end{array}$ \\
\hline Tetrahydrofuran & 2.08 & $2577.9 \pm 1.1$ & 112.0 \\
Di-butyl ether & $3.05^{8}$ & $2590.8 \pm 0.4$ & 99.1 \\
1,4-Dioxane & 3.22 & $2591.8 \pm 0.3$ & 98.1 \\
l,2-Dimethoxyethane & 3.27 & $2596.7 \pm 0.3$ & 93.2 \\
Diethyl ether & 3.59 & $2593.2 \pm 0.5$ & 96.7 \\
sec-Butyl phenyl ether & 5.36 & $2622.4 \pm 0.4$ & 67.5 \\
o-Methoxytoluene & 5.87 & $2629.5 \pm 0.4$ & 60.4 \\
Ethoxybenzene & 6.44 & $2629.1 \pm 0.4$ & 60.8 \\
Methoxybenzene & 6.54 & $2632.6 \pm 1.0$ & 57.3 \\
\hline
\end{tabular}

${ }^{a}$ Frequency of $\mathrm{O}-\mathrm{D}$ band in carbon tetrachloride $2689.9 \pm 0.5 \mathrm{~cm}^{-1}$.

values vary between 2 and 6.5, were studied. When the measured band shifts are plotted against the $\mathrm{p} K_{\mathrm{a}}$ values given by Arnett, ${ }^{2}$ a linear plot is obtained (Fig. 1); the $\mathrm{p} K_{\mathrm{a}}$ value determined by Fomin and Maslova ${ }^{8}$ was used for dibutyl ether. A straight line was fitted by the method of least squares (eqn. 1).

$$
\mathrm{p} K_{\mathrm{a}}=(0.0789 \pm 0.0042) \Delta v-(10.91 \pm 0.34)
$$

Acta Chem. Scand. 23 (1969) No. 5 
Fig. 1. The relationship between the basicity of the solvent and the $\mathrm{O}-\mathrm{D}$ band shift of methanol- $d_{1}$ in different solvents of the ether type ROR'.

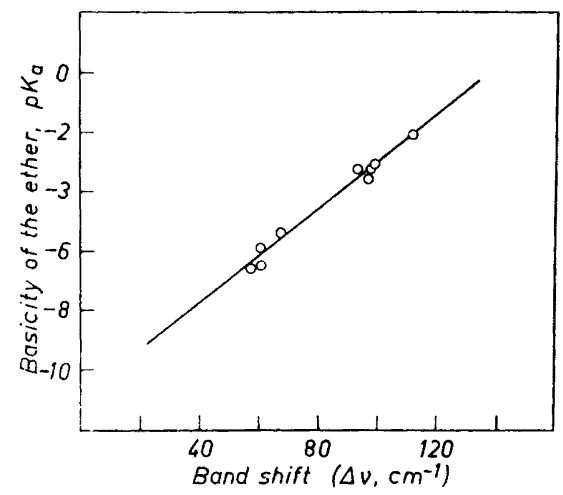

The spectral data for the studied dialkoxymethanes are collected in Table 2 together with the $\mathrm{p} K_{\mathrm{a}}$ values calculated from eqn. (1). A variation of about $5 \mathrm{p} K_{\mathrm{a}}$ units is found for the studied acetals. The maximum relative errors of these $\mathrm{p} K_{\mathrm{a}}$ values calculated from the standard errors of eqn. (1)

Table 2. $\mathrm{O}-\mathrm{D}$ band shifts of methanol-d in different acetals $\mathrm{R}_{n} \mathrm{OCH}_{2} \mathrm{OR}_{m}$ and $\mathrm{p} K_{\mathrm{a}}$ values of the conjugate acids of these acetals at $25^{\circ} \mathrm{C}$.

\begin{tabular}{|c|c|c|c|c|c|}
\hline $\mathrm{R}_{n}$ & $\begin{array}{l}\text { Substituents } \\
\qquad \mathbf{R}_{m}\end{array}$ & $\begin{array}{c}\mathrm{O}-\mathrm{D} \text { band } \\
\text { position } \\
\left(\mathrm{cm}^{-1}\right)\end{array}$ & $\begin{array}{c}\text { Band } \\
\text { shift } \\
\left(\mathrm{cm}^{-1}\right)\end{array}$ & $-\mathrm{p} K_{\mathrm{a}}$ & Ref. \\
\hline $\mathrm{CH}_{3}$ & $\mathrm{CH}_{3}$ & $2609.5 \pm 0.8$ & 80.4 & 4.57 & This work \\
\hline $\mathrm{CH}_{3} \mathrm{CH}_{2}$ & $\mathrm{CH}_{3} \mathrm{CH}_{2}$ & $2604.0 \pm 0.5$ & 85.9 & 4.13 & " " " \\
\hline$\left(\mathrm{CH}_{3}\right)_{2} \mathrm{CH}$ & $\left(\mathrm{CH}_{3}\right)_{2} \mathrm{CH}$ & $2598.5 \pm 0.5$ & 91.4 & 3.70 & $"$ \\
\hline$\left(\mathrm{CH}_{3}\right)_{3} \mathrm{C}$ & $\left(\mathrm{CH}_{3}\right)_{3} \mathrm{C}$ & $2587.7 \pm 0.2$ & 102.2 & 2.85 & $"$ \\
\hline $\mathrm{FCH}_{2} \mathrm{CH}_{2}$ & $\mathrm{FCH}_{2} \mathrm{CH}_{2}$ & $2614.9 \pm 0.7$ & 75.0 & 4.99 & $"$ \\
\hline $\mathrm{ClCH}_{2} \mathrm{CH}_{2}$ & $\mathrm{ClCH}_{2} \mathrm{CH}_{2}$ & $2619.0 \pm 0.4$ & 70.9 & 5.32 & $"$ \\
\hline $\mathrm{F}_{3} \mathrm{CCH}_{2}$ & $\mathrm{~F}_{3} \mathrm{CCH}_{2}$ & $2658.1 \pm 0.2$ & 31.8 & 8.40 & 4 \\
\hline $\mathrm{Cl}_{3} \mathrm{CCH}_{2}$ & $\mathrm{Cl}_{3} \mathrm{CCH}_{2}$ & $2651.1 \pm 0.3$ & 38.8 & 7.85 & $"$ \\
\hline $\mathrm{C}_{6} \mathrm{H}_{5}$ & $\mathrm{C}_{6} \mathrm{H}_{5}$ & $2631.7 \pm 0.2$ & 58.2 & 6.53 & \multirow{2}{*}{ This work } \\
\hline $\mathrm{CH}_{3}^{\circ}$ & $\mathrm{CH}_{3} \mathrm{CH}_{2}$ & $2606.1 \pm 0.5$ & 83.8 & 4.30 & \\
\hline $\mathrm{CH}_{3}$ & $\left(\mathrm{CH}_{3}\right)_{2} \mathrm{CH}$ & $2602.5 \pm 0.4$ & 87.4 & 4.01 & " " " \\
\hline $\mathrm{CH}_{3}$ & $\mathrm{ClCH}_{2} \mathrm{CH}_{2}$ & $2609.6 \pm 0.3$ & 80.3 & 4.57 & $"$ \\
\hline $\mathrm{CH}_{3} \mathrm{CH}_{2}$ & $\mathrm{ClCH}_{2} \mathrm{CH}_{2}$ & $2607.3 \pm 0.3$ & 82.6 & 4.39 & $"$ \\
\hline $\mathrm{CH}_{3} \mathrm{CH}_{2}$ & $\left(\mathrm{CH}_{3}\right)_{2} \mathrm{CH}$ & $2603.4 \pm 0.4$ & 87.3 & 4.02 & $"$ \\
\hline$\left(\mathrm{CH}_{3}\right)_{2} \mathrm{CH}$ & $\mathrm{ClCH}_{2} \mathrm{CH}_{2}$ & $2602.1 \pm 0.5$ & 87.8 & 3.98 & $"$ \\
\hline$\left(\mathrm{CH}_{3}\right)_{2} \mathrm{CH}$ & $\mathrm{Cl}_{3} \mathrm{CCH}_{2}$ & $2606.5 \pm 0.5$ & 83.4 & 4.33 & $"$ \\
\hline
\end{tabular}

are about $10 \%$. As the basicities of the studied acetals are compared with each other, the errors of these differences are much smaller than those of the $\mathrm{p} K$ values themselves as a result of the similar structures of the studied compounds. Fairly good estimates of these errors can be obtained on the basis of the standard errors of the measured band shifts. Relative errors less than three per cent are obtained in this way.

Acta Chem. Scand. 23 (1969) No. 5 
Dissection of the basicities of the acetals. The basicities of the oxygen atoms in acetals $\mathrm{R}_{n} \mathrm{OCH}_{2} \mathrm{OR}_{m}$ can be calculated on the basis of the measured $\mathrm{p} K_{\mathrm{a}}$ values. Let us denote by $K_{n m}{ }^{n}$ and $K_{n m}{ }^{m}$ the different equilibrium constants:

$$
\begin{aligned}
\mathrm{R}_{n} \mathrm{OCH}_{2} \mathrm{OR}_{m} \underset{K_{n m}^{n}}{\stackrel{\mathrm{H}_{3} \mathrm{O}^{+}}{\rightleftharpoons}} \mathrm{R}_{n} \mathrm{OCH}_{2} \mathrm{OR}_{m} \\
\mathrm{R}_{n} \mathrm{OCH}_{2} \mathrm{OR}_{m} \underset{K_{n m}^{m}}{\stackrel{\mathrm{H}_{3} \mathrm{O}^{+}}{\rightleftharpoons}} \mathrm{R}_{n} \mathrm{OCH}_{2} \mathrm{OR}_{+}
\end{aligned}
$$

The lower index pair refers to the substituents $R_{n}$ and $R_{m}$ of the acetal and the upper index to the site of protonation in question. We can assume that the alkyl group $\mathrm{R}$ which is not directly attached to the oxygen atom whose protonation is being discussed has only a negligible influence on the basicity of this hetero atom owing to the long distance. This assumption is reasonable on the basis of Taft's $\sigma^{*}$ values of different substituents. The polar constants of, e.g., methyl and hydrogen differ about 0.50 units, but the inductive effects of these substituents decrease markedly with the distance as can be seen from the nearly equal $\sigma^{*}$ values of the groups $\mathrm{CH}_{3} \mathrm{OCH}_{2}$ - and $\mathrm{HOCH}_{2}-{ }^{9}$ Thus

$$
\mathrm{p} K_{n m}{ }^{n}=\mathrm{p} K^{n}
$$

The overall equilibrium constant measured for an unsymmetrical acetal can be expressed in the form:

$$
1 / K_{n m}=1 / K^{n}+1 / K^{m}
$$

For a symmetrical acetal, the basicities of both oxygen atoms are naturally equal and thus

In $\mathrm{p} K$ units

$$
\begin{aligned}
1 / K_{n m} & =2 / K^{n} \quad(n=m) \\
\mathrm{p} K^{n} & =\mathrm{p} K_{n m}-\log 2
\end{aligned}
$$

When the $\mathrm{p} K$ values of the symmetrical acetals in Table 2 are substituted into this equation, the following basicities of the different oxygen atoms are obtained:

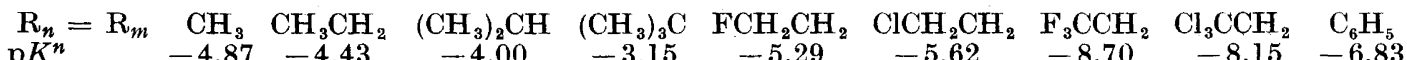

When these $\mathrm{p} K^{n}$ values are plotted against Taft's $\sigma^{*}$ values for alkyl groups, a linear relationship is found (Fig. 2) between the basicity of an oxygen atom and the electron-releasing or electron-attracting power of the substituent attached directly to this oxygen atom.

To evaluate the validity of eqn. (3), the overall $\mathrm{p} K$ values of the unsymmetrical acetals studied in this work were calculated from eqn. (4) and are compared below with the experimental basicities: 
Fig. 2. The relationship between the basicity of the oxygen atom and the polar substituent constant $\sigma^{*}$ of the neighbouring alkyl group for acetals of formaldehyde. The $\sigma^{*}$ values of $\beta$-fluoroethyl and $\beta, \beta, \beta$ trichloroethyl have been estimated by a previously described method. ${ }^{10}$

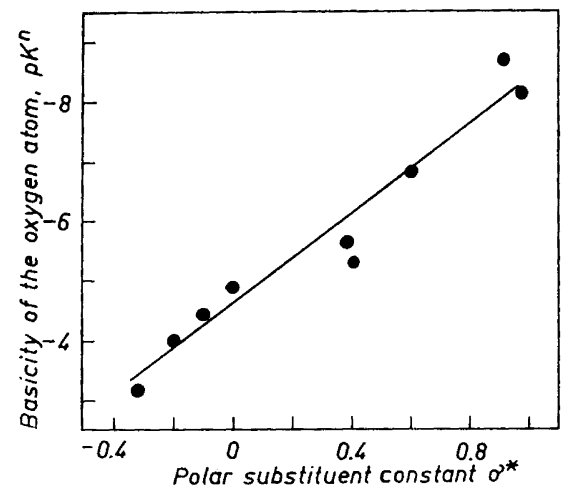

$$
\begin{array}{lccccccc}
\mathrm{R}_{n} & \mathrm{CH}_{3} & \mathrm{CH}_{3} & \mathrm{CH}_{3} & \mathrm{CH}_{3} \mathrm{CH}_{2} & \mathrm{CH}_{3} \mathrm{CH}_{2} & \left(\mathrm{CH}_{3}\right)_{2} \mathrm{CH} & \left(\mathrm{CH}_{3}\right)_{2} \mathrm{CH} \\
\mathrm{R}_{m} & \mathrm{CH}_{3} \mathrm{CH}_{2} & \left(\mathrm{CH}_{3}\right)_{2} \mathrm{CH} & \mathrm{ClCH}_{2} \mathrm{CH}_{2} & \left(\mathrm{CH}_{3}\right)_{2} \mathrm{CH} & \mathrm{ClCH}_{2} \mathrm{CH}_{2} & \mathrm{ClCH}_{2} \mathrm{CH}_{2} & \mathrm{Cl}_{3} \mathrm{CCH}_{2} \\
\mathrm{pK} \text { (calc.) } & -4.30 & -3.95 & -4.80 & -3.86 & -4.40 & -3.99 & -4.00 \\
\mathrm{pK} \text { (obs.) } & -4.30 & -4.01 & -4.57 & -4.02 & -4.39 & -3.98 & -4.33
\end{array}
$$

It is seen that these values are equal within the limits of experimental error.

\section{REFERENCES}

1. Salomaa, P. Ann. Acad. Sci. Fennicae, Ser. A II (1961) No. 103.

2. Arnett, E. M. In Cohen, S. G., Streitwieser, A. and Taft, Jr., R. W. Progress in Physical Organic Chemistry, Interscience, New York 1963, Vol. 1, 223.

3. Salomaa, P. and Linnantie, R. Acta Chem. Scand. 14 (1960) 777.

4. Kankaanperä, A. and Lahti, M. Unpublished results.

5. Vogel, A. I. Practical Organic Chemistry, 3rd Ed. 1967, pp. 669-671.

6. Kagiya, T., Sumida, Y. and Inoue, T. Bull. Chem. Soc. Japan 41 (1968) 767.

7. Pletcher, T. and Cordes. E. H. J. Org. Chem. 32 (1967) 2294.

8. Fomin, V. V. and Maslova, R. N. Russ. J. Inorg. Chem. 6 (1961) 243; Ref. Searles, Jr., S. and Tamres, M. In Patai, S. The Chemistry of the Ether Linkage, Interscience, London 1967, p. 261.

9. Taft, Jr., R. .W. J.Am. Chem. Soc. 75 (1953) 4231.

10. Taft, Jr., R. W. In Newman, M. S. Steric Effects in Organic Chemistry, Wiley 1956, p. 592 .

Received November 15, 1968. 